\title{
Service recovery following dysfunctional consumer participation
}

\author{
SALLY A. HIBBERT ${ }^{1 *}$, MARIA G. PIACENTINI ${ }^{2}$ and MARGARET K. HOGG ${ }^{2}$ \\ ${ }^{1}$ Nottingham University Business School Jubilee Campus, Wollaton Road, Nottingham NG8 1BB, UK \\ ${ }^{2}$ Department of Marketing, Lancaster University Management School, Lancaster University, Lancaster, UK
}

\begin{abstract}
This article introduces the notion of dysfunctional consumer participation. It advances a theoretical model of service recovery for contexts in which the smooth functioning of a service has been disrupted by consumers' dysfunctional contributions, founded on justice theory and cognitive appraisal theory. The model presents perceived justice as the core element of the evaluation of service recovery encounters. Stressful appraisal evokes emotions in consumers and influences the cooperative or resistant nature of consumer participation in service recovery processes directly and indirectly via its impact on consumers' emotions. Dysfunctional consumer participation is represented as an interactional process in which resistant consumer participation in service recovery provokes an adaptive response from service providers. Outcomes of the service recovery process for consumers and organisations are outlined. The contribution of this work lies in the domain of transformative consumer research, and our proposed framework enables managers with commercial (e.g., customer retention, sales) and social responsibilities (e.g., staff stress, consumer welfare) to analyse situations in which consumers' actions have disrupted the smooth functioning of services and consider strategies to restore workable relationships with them. Copyright (C) 2012 John Wiley \& Sons, Ltd.
\end{abstract}

\section{INTRODUCTION}

It has long been recognised that consumer participation in service delivery is vital for productivity and mutual value creation (Beuningen et al., 2009; Bowen, 1986; Lovelock and Young, 1979). Hitherto, research into disruptions to service functioning has concentrated almost exclusively on firms' failure to meet customer expectations and appropriate service recovery strategies (Grönroos, 1988; Sharma, 2008). However, there is growing recognition that sometimes consumers behave in ways that are problematic and that inhibit the smooth functioning of services (Harris and Reynolds, 2004). There is no research that examines how to best recover workable relationships with consumers under these circumstances, and this is the focus of this article.

Problematic consumer conduct can include skipping payments, late payments, breaking rental agreements, repeatedly calling customer care lines, and aggressive behaviour towards staff and other customers. Such norm-violating behaviours are not confined to minority segments of the population but are a pervasive part of everyday consumer behaviour (Fullerton and Punj, 2004). The behaviour is sometimes deliberate or sometimes the result of thoughtlessness (Fullerton and Punj, 1997a). However, it can also result when a consumer lacks control over the situation or lacks knowledge or experience of roles and responsibilities (Bitner et al., 1997). Addressing problematic consumer behaviour is a tricky and sensitive process, particularly when organisations are unable to differentiate between consumers who are deliberately disruptive, those whose behaviour is unintentionally disruptive, and those consumers trying to cope with factors that are beyond their control.

* Correspondence to: Sally A. Hibbert, Nottingham University Business School, Jubilee Campus, Wollaton Road, Nottingham NG8 1BB, UK. E-mail: sally.hibbert@nottingham.ac.uk
Research into service recovery strategies notes that consumers' reactions to service recovery efforts are determined by the perceived fairness of the strategy and the emotions evoked, which influences consumers' satisfaction, loyalty intentions, and word of mouth (Goodwin and Ross, 1992; McColl-Kennedy and Sparks, 2003; Tax et al., 1998). In many contexts, consumers do not simply react to recovery attempts by evaluating fairness but are actively involved in service recovery processes, and evidence suggests that consumer participation in recovery encounters influences outcomes (Dong et al., 2008). Service recovery scholarship has provided valuable insights that are applicable to service recovery in circumstances where service provider-consumer relations have been disrupted due to problematic consumer contributions. However, there is no prior research that specifically examines this problem.

This article takes a first step in addressing questions of how to manage service recovery when consumer participation goes awry. It introduces the notion of dysfunctional consumer participation (DCP) and addresses the following research questions:

(1) What strategies can be used to recover a workable relationship with consumers following DCP?

(2) How do consumers evaluate service recovery strategies that organisations implement following DCP and what are their emotional reactions?

(3) How do consumers' cognitive and emotional reactions to such service recovery strategies influence their participation in service recovery?

(4) How do interactive service recovery processes impact on the outcomes for consumers and organisations?

As our core contribution to transformative consumer research, we propose a framework to enable scholars and managers to evaluate strategies to restore workable relationships with consumers following disruptions. The framework also outlines the consequences of service recovery encounters for consumers and organisations, which are significant for 
managers responsible for commercial outcomes (e.g., customer retention, sales) and also in regard to social responsibilities (e.g., staff stress, consumer welfare). The article is organised as follows. First, we draw on literature on consumer participation, consumer vulnerability, and dysfunctional consumer behaviour to define DCP. We briefly review literature on service recovery before presenting a conceptual model of service recovery for contexts in which consumers' dysfunctional participation contributes to tensions or to the breakdown in relations. Finally, we discuss the theoretical and practical implications of the research and advance suggestions for future research to develop knowledge in this area of service recovery.

\section{DEFINING DCP}

Consumers interact with service products, employees, systems, and other consumers to realise service outcomes (Vargo and Lusch, 2008). In its broadest sense, consumer participation extends to activities such as helping other consumers, but research into consumer participation has tended to focus on in-role behaviours, which are 'required behaviours necessary for the successful service creation' (Yi et al., 2011: 88). Early research examining ways of encouraging consumer participation in service delivery adopted a view of consumers as 'partial employees', applying employee management models (e.g., organizational socialization) to build understanding of ways to improve participation and satisfaction with the outcomes (Claycombe et al., 2001; Dabholkar, 1990; Kelley et al., 1992). More recent research has been concerned with understanding consumers' motives and capabilities to engage in participative behaviours and meet role expectations. Within this stream of research, considerable effort has been devoted to understanding the role of consumer knowledge and skills in driving consumer contributions to productivity. There is a growing body of evidence that consumer education and training can increase the likelihood of successful consumer participation via their effect on role readiness variables (role clarity, ability, and motivation) (Dellande et al., 2004; Meuter et al., 2005). However, all of this work has concentrated on consumer participation in unproblematic service encounters. Here, we are concerned with instances when consumer behaviour during service encounters does not conform to role expectations of the service provider and most other consumers (Biddle, 1986; Bitner et al., 1994), and this is what we refer to as DCP.

Dysfunctional consumer participation can be unintentional, for instance, when consumers lack clarity about their role or do not have the necessary resources to comply with role expectations, or intentional, such that consumers deliberately violate accepted norms of conduct (Fullerton and Punj, 1993). Insights into unintentional DCP can be derived from the consumer participation literature and research into consumer vulnerability. Although scholarship concerned with facilitating consumer participation has emphasised that consumers need knowledge or skills to coproduce services, the broader cocreation literature recognises that consumers require a range of operand (e.g., physical spaces, material objects) and operant (e.g., knowledge, skills, social connections) resources to perform participative roles (Payne et al., 2008). Consumer participation scholarship has not examined how constraints across this range of resources affect consumer contributions, but research into consumer vulnerability has provided ample evidence that consumers who lack resources (e.g., low-income consumers, low-literature consumers, consumers with weak social networks or low social status) are severely inhibited in meeting their needs in the marketplace (Andreasen, 1975; Hill and Stephens, 1997). Research into healthcare for an Appalachian community, for instance, illustrated that restricted financial resources (i.e., lack of money to pay for tests and medication) inhibited compliance with the prescribed treatment, and their low social status diminished their voice during service encounters (i.e., physicians did not properly attend to the information provided on symptoms) (Lee et al., 1999). Consumer vulnerability research emphasises that resource constraints create a state of powerlessness for consumers that negatively impacts on the outcomes of marketplace exchanges (Baker et al., 2005). Elaborating on power imbalances in the marketplace, scholars have suggested that service encounters and relationships are unsuccessful not because of the consumer's resource constraints per se but because service providers fail to appreciate or are not sensitive to the resource limitations of particular groups (Adkins and Ozanne, 2005; Baker and Kaufmann-Scarborough, 2001; Kaufman-Scarborough and Baker, 2005; Penaloza, 1995; Viswanathan et al., 2005). Lee et al. (1999) challenged the bipolar view of service provider-consumer roles, arguing that service encounters are structured around different resources (economic, social, and cultural) and highlighting that organisations need to understand the resource strengths and priorities of various consumer segments and adopt practices that are sensitive to them to deliver satisfactory service encounters.

More deliberate violation of expected role performance is illuminated by the literature on dysfunctional consumer behaviour (Bitner et al., 1994; Fullerton and Punj, 1993; 1997a; Harris and Reynolds, 2003; Lovelock, 2001). In this case, consumer predispositions interact with features of the context to influence consumer misbehaviour (Fullerton and Punj, 1993). Factors underpinning consumer predispositions include consumer traits (e.g., sensation seeking, aggressiveness, self-esteem), demographic factors (e.g., age, sex, education), and social influences (group norms, socialisation) (Daunt and Harris, 2011; Fullerton and Punj, 1993). Reynolds and Harris (2009) showed that consumers' predispositions to misbehave influence behaviour directly via their influence on consumers' appraisals of the servicescape (the tangible and intangible features of the services) and their disaffection with the service. Thus, Reynolds and Harris (2009) provided support for previous claims that perceptions of the servicescape (e.g., crowding, long queues, loud music) contribute to disaffection with the service and lead to negative behaviours (e.g., dumping a trolley full of groceries) (Baker and Cameron, 1996).

Although consumer participation has been defined in a general sense, we argue that DCP is distinct because of the nature and antecedents of consumer participation that disrupt the smooth functioning of services and the negative 
consequences for the organisation, its staff, other customers, and even the consumer himself or herself. We define DCP as 'consumer contributions to service creation and delivery that disrupt otherwise functional service encounters, whether deliberately or unintentionally, from a position of control or powerlessness'. Any particular instance of disruptive behaviour could be deliberate, thoughtless, unintentional, or genuinely beyond the person's control, and organisations need to develop service recovery strategies for restoring a smoothly functioning service that can deal with these different circumstances. The various explanations for different consumers' DCP make it a complicated management issue for those responsible for recovery strategies, yet there is very little research to guide managers facing this challenge. The next section draws on the service recovery and complaint handling literature, as well as customer value management research, to develop insights into recovering workable relationships with consumers following DCP.

\section{SERVICE RECOVERY}

The perfect, error-free organisation that never slips up or encounters problems that impact on consumers is unimaginable. The fact that service failure is almost inevitable (Bitner et al., 1990) does not make it any more acceptable to consumers, and it jeopardises the relationship between an organisation and its customers, threatening repeat patronage and loyalty (Webster and Sundaram, 1998) and generating negative word of mouth. These consumer reactions have considerable economic implications for organisations (Hart et al., 1990), and much research attention has been devoted to service failure (Grönroos, 1988; Sharma, 2008).

Service recovery research has sought to examine the service recovery strategies of organisations (Davidow, 2003) and the consumer outcomes following organisations' service recovery attempts (Smith et al., 1999). Service recovery strategies include refunds, replacements, apologies, and upgrades (Bitner et al., 1990; Tax et al., 1998;). Homburg and Fürst (2005) compared mechanistic and organic approaches with complaint management and found that the two approaches are complementary but their relative impact varies depending on the context. However, many organisations still struggle to manage customer complaints effectively (Homburg and Fürst, 2007).

Primary outcomes of service recovery include satisfaction, word of mouth, and repurchase intentions (Blodgett et al., 1997; Maxham, 2001). Justice theory has been widely adopted to build understanding of why consumers regard particular service recovery strategies more or less favourably. There is ample evidence that the perceived fairness of the organisation's response mediates the effects of service recovery on outcomes (Goodwin and Ross, 1992; Tax et al., 1998; McColl-Kennedy and Sparks, 2003) along with consumers' emotional reactions (DeWitt et al., 2008; Gregoire et al., 2010; Río-Lanza et al., 2009). The implicit assumption within this body of literature is that the consumer's role is restricted to their evaluation of the service recovery strategy. In contrast, Dong et al. (2008) introduced the notion of cocreated service recovery, promoting the view that service recovery is an interactional process, with consumers actively contributing to realising service recovery outcomes. They defined consumer participation in service recovery as 'the degree to which the consumer is involved in taking actions to respond to a service failure' (p. 126) and demonstrated that it influences satisfaction with service recovery but also that it affects the perceived value of future cocreation and role readiness for future cocreation. These three factors, in turn, influence intention for future cocreation.

In the same way that organisations are almost certain to make mistakes, so too will consumers' behaviour disrupt the smooth functioning of services at some point. Given the inevitability of DCP and the fact that it is similarly costly for organisations, it is surprising that service disruptions due to DCP have been so neglected and that there is no literature that examines service recovery following DCP.

To enable scholars and managers to fully understand service recovery following DCP requires a theoretical framework that outlines how organisations' responses to service disruptions following DCP influence participation in service recovery processes and the impact on outcomes. In the next part of this article, we advance a model that is grounded in the service recovery literature but draws on research into consumer participation, customer value management, consumer vulnerability, and dysfunctional consumer behaviour.

\section{MODEL OF SERVICE RECOVERY FOLLOWING DCP}

\section{Overview of the framework}

Figure 1 outlines a framework that focuses on service recovery following DCP. It is presented as an interaction framework in which the organisation's approach to service recovery and the consumer's participation in the process influence the outcomes. In keeping with other literature on service recovery, cognitive appraisal theory and justice theory provide the theoretical foundation for the model. However, our framework contrasts with earlier models of service recovery, which typically regard it as a process in which the organisation implements a service recovery strategy and the consumer responds by evaluating the action taken. Instead, our model is consistent with the view of Dong et al. (2008) that service recovery encounters are interactional; there are few instances when consumers are not required to perform at least some role in the process, and outcomes are influenced by both the technical quality (what they do) and functional quality (how they behave) of their contributions. This is in keeping with the literature on managing 'bad' customers, which will be covered later, that suggests various strategies that involve working with consumers as key mechanisms by which a workable relationship can be restored (Mittal et al., 2008). Hence, where deficient consumer contributions have contributed to disrupting the consumer-service provider relationship, a service recovery process that acknowledges its interactive nature should represent a more successful approach to restoring a smoothly functioning service and reducing the risk of problems recurring in the future.

There are four core elements to the model: (i) organisational strategies to manage DCP; (ii) consumers' justice perceptions 


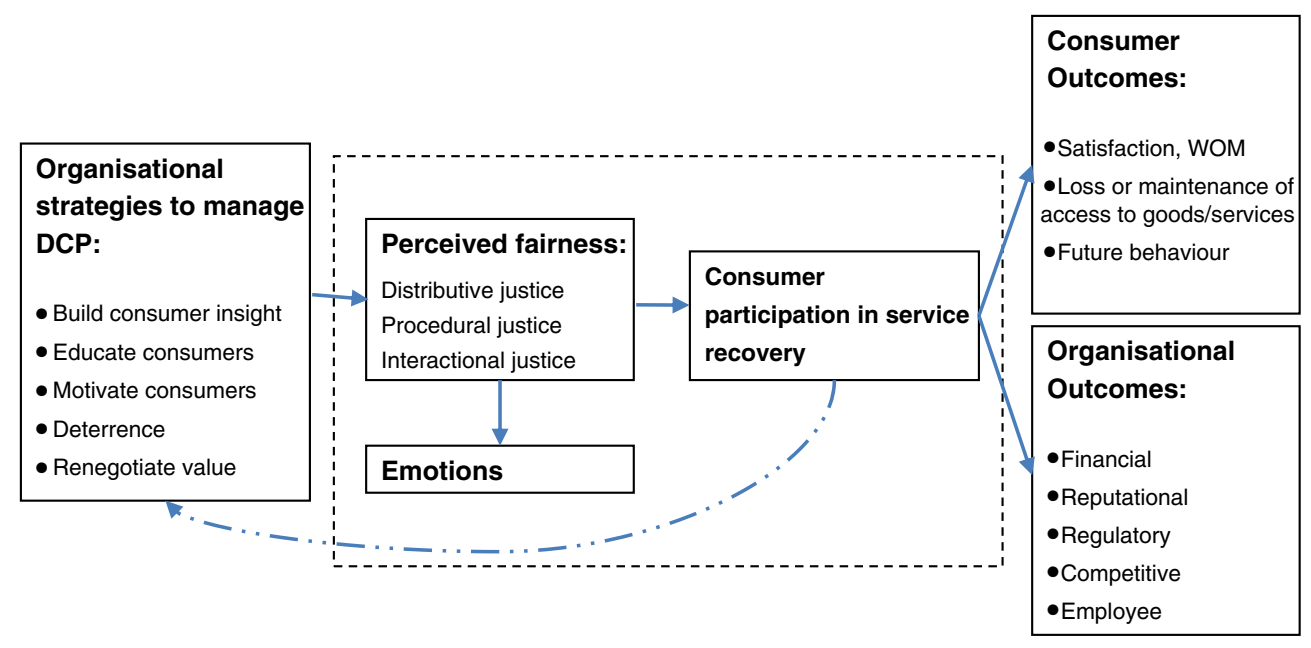

Figure 1. Process of service recovery following dysfunctional consumer participation (DCP).

and emotional reactions; (iii) consumer participation in service recovery; and (iv) consumer and organisational outcomes. The part of the model for which we advance research propositions is within the central broken-lined box. We acknowledge that personal and situational factors, along with the type of service and service delivery format, may all influence consumers' inclination to engage in service recovery processes. In particular, those factors that explain the DCP that leads to service disruption are expected to moderate consumers' response to recovery strategies. However, we do not examine these relationships here but rather concentrate on the core relationships between organisations' responses to DCP, consumers' evaluative and emotional responses, participation in service recovery, and the outcomes in an attempt to establish the significant implications of service recovery following DCP. The moderating role of personal and contextual factors that might influence this process individually, or in combination, requires a depth programme of inquiry that is more suitable for future research.

\section{Organisational strategies to manage DCP}

Service recovery is defined as actions taken by organisations following service failure to rectify, amend, or restore the losses incurred (Grönroos, 1988), typically compensating customers or issuing an apology (Tax et al., 1998). Consistent with service recovery following failures by the organisation, service recovery following DCP tends to be directed at restoring losses (e.g., recouping costs of staff time through financial penalties), but it is distinctive in that it also seeks to protect against future losses by making adjustments to the service relationship (e.g., shifting the consumer onto a different type of service contract that limits the amount of consumer support provided) or by seeking to influence consumers' future participation (e.g., suspending service access, imposing penalties to discourage late payment in the future). Accordingly, we define service recovery following DCP as 'actions taken by organisations to restore losses and/or protect against future losses'.

There is a range of strategies that organisations can deploy to manage DCP. Consumer participation scholarship indicates that educating and motivating consumers improves their contributions to service quality (Kelley et al., 1992; Meuter et al.,
2005). The advocacy of a resource-sensitive approach to service delivery within the consumer vulnerability literature implies that when consumers fail to perform roles as expected due to resource constraints, organisations' strategies for recovering the relationship need to involve building a better understanding of consumers' needs and capacities and adapting service provision (Baker and Kaufmann-Scarborough, 2001; Lee et al., 1999). Literature on dysfunctional consumer behaviour suggests that education and deterrence are the primary ways of controlling misbehaviour. Fullerton and Punj (1997b) suggested that consumer education can contribute to the management of dysfunctional consumer behaviour by helping consumers to "unlearn patterns of misconduct and to strengthen moral constraints which inhibit misbehaviour' (p. 340) (for instance, organisations highlighting that misbehaviour is not victimless). However, they also noted that dysfunctional consumer behaviour is most commonly controlled by deterrence mechanisms. Punishments can have a reparatory effect of restoring losses (e.g., fines), but, importantly, deterrent mechanisms protect against misbehaviour by creating perceived risks. Organisations need to develop effective detection mechanisms and to consistently apply punishments if deterrence is to be successful in protecting against consumer misbehaviour. Deterrence mechanisms are associated with wilful misbehaviour such as shoplifting, but they are also widely used for less serious DCP such as late bill payment and failure to conform to rental agreements (e.g., returning a hire car later than specified). Although a potentially effective means of influencing consumer behaviour, deterrence has to be carefully designed to avoid alienating consumers.

Finally, there is a small substream of literature amongst the customer value management research that has provided some insights relevant to the management of problematic consumers (Mittal et al., 2008; Zeithaml et al., 2001; Zhao et al., 2009). This scholarship advocates the segmentation of consumers based on their profitability or risk level, building understanding of each segment and developing strategies that aim either to transform low-value consumers into more profitable ones or to adapt the offering to meet their needs profitably. Mittal et al. (2008) propose that organisations ask four key questions to assess whether there are alternative 
options to getting rid of problematic consumers. First, has the company misunderstood or mishandled consumers? If so, they proposed that the relationship needs to be reassessed. Second, are the consumers inclined to understand the company's position? If consumers are likely to empathise, then educating consumers is a viable option to recover a workable relationship. Third, can the consumers and the company find new ways to reap value from each other? In which case, there may be scope to renegotiate the value proposition. Finally, might the consumers be profitable for subsidiaries or other providers? An affirmative answer to this question suggests that migrating the consumers is a potential solution. Only in the event that none of these questions are answered in the affirmative should customer divestment be considered a primary strategic option to deal with the segment. Building consumer insight, educating and providing feedback to consumers, and renegotiating the value proposition are comparable with approaches found in the other streams of literature. Building understanding of consumers and renegotiating the value proposition are consistent with the consumer vulnerability literature, whereas educating consumers is consistent with the consumer participation and dysfunctional consumer behaviour literature.

In summary, there is a range of strategies that organisations can use in an effort to recover workable relationships with consumers following DCP. These strategies may be used individually or in combination. For instance, deterrence strategies may be used alongside consumer education to reduce negative consumer reactions and protect against the recurrence of DCP. The strategies derived from these streams of literature offer useful directions for managers responsible for service recovery following DCP, but there is very little research in any of these areas that examines either how consumers respond or how these strategies play out when implemented.

\section{Perceived fairness: Consumers' evaluations of service recovery following $\mathrm{DCP}$}

Within service recovery scholarship, justice theory has been widely applied to build understanding of consumers' reactions. Konovsky (2000) argued that justice theory is a useful framework for situations characterised by conflict. It is likely that when organisations respond to DCP by imposing penalties, issuing warnings, or even calling up the consumer to discuss the problem, evaluations of fairness will be central to consumers' responses.

Consumers' cognitive evaluations of organisations' recovery efforts encompass the perceived distributive, procedural, and interactional justice of the strategy (Goodwin and Ross, 1992). Distributive justice is concerned with the allocation of benefits and costs and typically defined as 'what the customer receives as the outcome of a recovery process' (McCollKennedy and Sparks, 2003: 253). Various suggestions have been advanced about the basis of individuals' judgements on allocation. Goodwin and Ross (1992) suggested that consumers may apply different allocation rules (e.g., an equity rule, such that outcomes are shared equally, or a needs rule, which suggests that outcomes are allocated according to perceived needs), whereas Tax et al. (1998) proposed that consumers judge fairness based on what they know about the treatment of other consumers in similar situations, their own prior experience, and their perceptions of their own losses. Tax et al. (1998) concluded that distributive justice is best operationalised in general terms to capture whether the outcome was deserved, was fair, and met the consumer's needs. Consumers may be content with recovery strategies following DCP if they end up better able to meet their needs, although recovery strategies involving warnings, fines, or penalties are likely to irritate. However, even in situations where the outcomes are undesirable, consumers are more likely to be cooperative and open to a positive future relationship with the service provider if they perceive the outcome to be deserved and fair and to take account of their resources. Thus, we propose:

\section{P1: Distributive justice is positively associated with cooperative participation in service recovery.}

Procedural justice refers to the fairness and transparency of the process used to resolve disputes. Tax et al. (1998) distinguished five formative factors that underpin the perceived justice of service recovery including the ease of access, the opportunity for the consumer to express a view, the consumer's degree of control over the outcome of a decision, flexibility of the process to reflect individual circumstances, and the timing and speed of the recovery process. On the point of consumers having the opportunity to express their view, Goodwin and Ross (1992) emphasised that it is only when the opportunity to have one's say is provided in the context of a responsive decision maker that it impacts on perceived fairness and enables the consumer to continue to respect the organisation. To express one's views and be ignored simply contributes to a sense of injustice. The policies and structures that govern the recovery procedure are important because the way in which the problem is resolved can help to restore a workable relationship even if the outcomes are undesirable (Greenberg, 1990). A fair procedure is particularly important for service recovery following DCP when the outcomes for consumers may be undesirable, potentially leading to feelings of vulnerability and alienation in relation to the service. Therefore, we propose that:

\section{P2: Procedural justice is positively associated with cooperative participation in service recovery.}

Interactional justice refers to the interpersonal exchanges between the service provider and consumer during service recovery procedures and the degree to which each party is treated with dignity and respect. Interactional justice has considerable impact on consumers' perceptions of service recovery (McColl-Kennedy and Sparks, 2003). Indeed, Tax et al. (1998) revealed that interactional justice was the most important determinant of trust in the organisation. Trust is considered to be a precondition for consumer participation (Lovelock and Young, 1979; Lusch et al., 1992; Mills and Morris, 1986), indicating that perceived interactional justice will be an important precursor to consumers' cooperative participation in service recovery. Some empirical support for this proposed relationship is provided by Auh et al. (2007) who showed that perceived interactional justice 
significantly influences consumer coproduction in the service delivery context and Funches et al. (2009) who found interactional injustice to be an important motivator for retaliatory behaviours. By contrast, in contexts where consumers' contributions are deficient, consumers may be pleasantly surprised by a courteous and empathetic response from the staff and more positively disposed to collaborating in the recovery encounter. Thus, we propose the following research proposition:

\section{P3: Interactional justice is positively associated with cooper- ative participation in service recovery.}

Although scholarship has demonstrated that all three aspects of justice impact on satisfaction and behavioural outcomes, Maxham and Netemeyer (2002) showed that procedural and interactional justice are particularly important in service contexts, whereas consumers are more focused on redress where durable goods are concerned. This reflects the role of service policies, processes, and people as central to the service offering and emphasises that it is equally as important to get these right in recovery situations as it is for service delivery. We anticipate that it will be particularly important for service recovery following DCP, given that role readiness, perceived control, and disaffection with the service are contributory factors in the incidence of DCP. For instance, if individuals fail to complete the paperwork necessary for successful service delivery either because they do not understand what information is required (e.g., complex tax returns) or because they are functionally illiterate, a flexible service recovery process allows extra time for the paperwork to be submitted. In these cases, help from the service staff or via other agencies is needed to restore smooth functioning of the service. Imposing penalties would be an inappropriate response.

\section{Emotional reactions to service recovery following DCP}

Several researchers have proposed that emotions are an important consumer response to service recovery that influences their behaviour and ultimate satisfaction with the process (Chebat and Slusarczyk, 2005; Gustaffson, 2009; McColl-Kennedy et al., 2011; Río-Lanza et al., 2009; Schoefer and Ennew, 2005). Researchers adopting both cognitive appraisal theory and affect control theory have advanced conceptualisations in which emotions are aroused following consumers' cognitive evaluations of the fairness of service recovery. Appraisal theorists maintain that individuals evaluate events in terms of their goal relevance and goal incongruence (Lazarus, 1991). Emotions are elicited when people consider that some aspect of their well-being is at stake and that an event will facilitate (positive emotions) or thwart (negative emotions) this stake. Schoefer and Ennew (2005) proposed that justice evaluations are an element of cognitive appraisal of service recovery strategies that arouses an emotional response in consumers. Chebat and Slusarczyk (2005) suggested that emotions are part of an affect control process and serve as a coping response to perceived injustice. These studies and more recent research by Río-Lanza et al. (2009) have provided evidence that each type of perceived justice influences consumers' negative emotional reactions to service recovery. Research has demonstrated that service recovery is associated with intense negative emotions but only mild positive emotions (Schoefer and Ennew, 2005), prompting other researchers to focus on negative emotions (Río-Lanza et al., 2009). However, other marketing scholars (DeWitt et al., 2008; Gustaffson, 2009) argued that if service providers handle recovery well, consumers may experience positive emotions (e.g., pleasure, happiness) that impact on their attitudes towards the organisation and their future behaviour. The theoretical underpinnings of this relationship should also hold true for service recovery following DCP. Therefore, we propose that:

\section{P4: Perceived distributional, procedural, and interactional justice are negatively associated with negative emotions.}

\section{P5: Perceived distributional, procedural, and interactional justice are positively associated with positive emotions.}

Justice theory holds that emotions play a key role in conveying justice perceptions to subsequent attitudes and behaviours (Weiss et al., 1999). Prior research based on this assumption has found that emotions evoked by service recovery strategies influence outcomes including satisfaction with service recovery (Río-Lanza et al., 2009; Schoefer and Ennew, 2005) and loyalty or exit (Chebat and Slusarczyk, 2005), mediating the effects of justice appraisals. In our framework, the immediate outcome of appraisal processes is consumers' participation in service recovery. In line with both the justice theory and appraisal theory, we propose that consumers' emotions mediate the effects of perceived justice on consumer participation in service recovery:

P6: Negative emotions are negatively associated with cooperative consumer participation in service recovery.

P7: Positive emotions are positively associated with cooperative consumer participation in service recovery.

Consumer participation in service recovery following DCP When Dong et al. (2008) introduced the notion of customer participation in service recovery, they were concerned with the level of consumer involvement in taking action in response to service failure. In the context of $\mathrm{DCP}$, we are more interested in the nature of consumer participation and how people behave in the face of particular service recovery strategies. When people participate in service recovery following DCP, they can either cooperate and perform their expected role to restore smooth functioning of the service or they can resist the proposed course of action, refusing, challenging, explaining, and negotiating with the service provider and even bringing in social support to argue their case. In many instances, consumers' contributions to service recovery encounters incorporate an element of both cooperation and resistance. Therefore, we conceptualise consumer participation in service recovery as a continuum ranging from highly cooperative to highly resistant.

Our model indicates that there is a feedback loop from consumer participation in service recovery to service recovery 
strategies. A service recovery encounter is an interactive, adaptive process for both parties, and a service provider may revise the service recovery outcomes, process, or interactions in response to a consumer's participation if the consumer resists either the service provider's prognosis of the DCP or the reparative course of action that it proposes. Even low-level acts of resistance such as providing reasons for the behaviour (e.g., 'I was unable to pay my bill on time because I was admitted to hospital', 'I didn't realise that you had to pay for the store's catalogue') can influence the service provider's decision about the service recovery strategy that is most appropriate. However, the adaptation does not always work in the consumer's favour, and it can result in the organisation taking a harder line on service recovery, for instance, if a consumer refuses to settle arrears, the service provider may resort to legal action to recover debts. Thus,

\section{P8: Resistant consumer participation in service recovery is positively associated with adaptation of service recovery strat- egies by service providers.}

\section{Outcomes of the service recovery process following DCP}

As with other forms of service recovery, service recovery following DCP will have consequences in terms of consumer satisfaction and word of mouth (Maxham, 2001; Singh, 1990). In terms of future behaviour, the outcome of the process affects a consumer's inclination to continue to patronise the service provider (Hart et al., 1990) and their likelihood of future dysfunctional participation (Dong et al., 2008) and even retaliatory behaviours (Keeffe et al., 2007), but it also affects their continued access to the service. If the recovery is unsuccessful from the service provider's point of view, the consumer may lose access to the service provided by a particular provider (e.g., being barred from a local supermarket) or from a set of providers (e.g., being added to an industry blacklist). Losing access to a service can have relatively minor consequences, like causing inconvenience or increased costs. However, it can also have major ramifications that influence an individual's life trajectory, for instance, when an individual loses his or her home or place at college. Access to services such as housing, utilities, transport, healthcare, telecommunications, and retailing is vital for individuals and families in meeting their needs. The literature on consumer vulnerability has demonstrated that lack of service access is a key source of disadvantage (Andreasen, 1975; Baker et al., 2005), although there is a lack of research that examines the implications of losing access to services. Some organisations have recognised the importance of these consequences and have contingencies such as hardship funds (e.g., utilities companies) and counselling services (e.g., educational institutions) to help consumers with genuine reasons for DCP that they cannot overcome without support.

For the organisation, there are financial and competitive consequences for the firm as a result of losing consumers who could potentially be profitable or as a consequence of negative word of mouth that impacts other consumers' propensity to patronise the organisation (Rosenblum et al., 2003; Rust et al., 2000). There are also reputational risks from negative word of mouth about an organisation's treatment of consumers, especially if they are considered vulnerable. Organisations are also subject to policy and regulatory pressures if they are seen to be acting unfairly. Finally, the process of service recovery following DCP can have various impacts on employees. It can be stressful and time consuming for employees to implement service recovery strategies, which can result in service disruptions and meet with opposition from consumers. There is plenty of evidence in the literature of dysfunctional consumer behaviour that workers often ignore incidences of misbehaviour to avoid confrontation and administrative processes involved in dealing with disruptive behaviour (Harris and Ogbanna, 2010; Reynolds and Harris, 2006). It can also be demotivating for employees who are involved in service recovery strategies that they believe to be unfair for consumers and at odds with their own values.

\section{CONCLUSIONS AND FUTURE RESEARCH}

\section{Theoretical contributions}

In this article, we introduce the notion of DCP and conceptualise the process of service recovery following disruption due to consumers' behaviour. The concept of DCP integrates three streams of literature, namely, consumer participation, dysfunctional consumer behaviour, and consumer vulnerability. This research contributes to the literature on consumer participation by examining problematic in-role behaviours and thus counterbalancing the predominance of research in this area that has focused on optimising largely unproblematic consumer participation (Auh et al., 2007; Eisingerich and Bell, 2006; 2008; Mittal and Sawhney, 2001). It introduces a novel dimension to the understanding of dysfunctional consumer behaviour, which has previously focused on more volitional acts of misbehaviour (Fullerton and Punj, 1993; Reynolds and Harris, 2009) and assumes that organisations can distinguish deviant actions from consumer behaviours that are not intentionally 'bad' when they seek to tackle them. Finally, the research demonstrates the relevance of consumer vulnerability to the service coproduction paradigm. It adds to previous research into consumption restrictions (Cornwell and Gabel, 1996; Hill, 1991; Litt et al., 2005) by showing how service encounters that entail expectations of consumer role performance and, very often, power imbalances can create stress for vulnerable consumers and threaten their continued access to services by which they meet core needs for themselves and their families.

This research contributes to the service recovery literature by identifying a range of strategies that organisations adopt as a means of recovering workable relationships with consumers and conceptualises the process by which service recovery following DCP is realised. It also adds to the neglected area of consumer participation in service recovery (Dong et al., 2008).

\section{Implications for practitioners}

All types of organisations-commercial, nonprofit, central and local government-face the challenge of managing DCP. In more extreme cases of DCP, where consumers intentionally 
and unrelentingly behave in ways that are damaging to the organisation, there is little hope or desire to maintain a relationship with the consumers concerned. Many other instances of DCP can be managed, however, and in these cases, consumer satisfaction should be an objective of service recovery processes. However, service recovery following DCP may result in consumer resistance, and the organisation needs to complement any mechanistic approaches to service recovery following DCP with an organic approach (Homburg and Fürst, 2005), training staff and giving them the power to make decisions about the appropriate adaptation of the service recovery strategy to fit the consumer's circumstances.

\section{Future research}

This article represents the first step in working towards a framework of service recovery following DCP. It is intended to stimulate discussion and to be the basis for further empirical and conceptual contributions. The core relationships conceptualised in this article need to be empirically examined to demonstrate the validity and reliability of the proposed relationships and to start to build understanding of which elements of justice and emotional responses are most influential on consumer participation in service recovery following DCP. Our conceptualisation concentrates on the core relationships in the service recovery process, and there is a need for future scholarship to identify and empirically test the range of individual and contextual factors that moderate the proposed relationships. Understanding of service recovery following DCP would also be advanced by undertaking research with frontline delivery staff about their experiences of service recovery processes.

\section{ACKNOWLEDGEMENTS}

The authors thank all the young people who participated in this study as well as the national children's charity Barnado's and the local government Morecambe Leaving Care Team for their generous assistance.

\section{BIOGRAPHICAL NOTES}

Sally Hibbert is an associate professor in marketing at the Nottingham University Business School. Her core expertise is in consumer behaviour, and she has a long-standing interest in the interface between consumption and society. She has published her work in a number of academic journals, including Journal of Service Research, Psychology \& Marketing, Journal of Business Research, Journal of Marketing Management, Journal of Business Ethics, European Journal of Marketing and Journal of Consumer Behaviour.

Maria Piacentini is a senior lecturer in marketing at the Lancaster University Management School. Her research focuses on vulnerable consumers, and she is concerned with the strategies employed by consumers in difficult consumption contexts and situations. She has published her work in a number of academic journals, including Journal of Marketing Management, Journal of Business Research, Sociology of Health and Illness, Journal of Consumer Behaviour, and Advances in Consumer Research.

Margaret Hogg is a Fulgoni professor of consumer research at the Lancaster University Management School, and her principal research focuses on the relationship between identity, self, and consumption. She has published her work in a number of academic journals, including Journal of Marketing Management, Journal of Advertising, Journal of Business Research, European Journal of Marketing, Journal of Services Marketing, and Advances in Consumer Research.

\section{REFERENCES}

Adkins NR, Ozanne JL. 2005. The Low Literate Consumer. Journal of Consumer Research 32 (June): 93-105.

Andreasen AR. 1975. The Disadvantaged Consumer. The Free Press: New York.

Auh S, Bell SJ, McLeod CS, Shih E. 2007. Co-production and Customer Loyalty in Financial Services. Journal of Retailing 83(3): 359-370.

Baker J, Cameron M. 1996. The Effects of the Service Environment on Affect and Consumer Perception of Waiting Time: An Integrative Review and Research Propositions. Journal of the Academy of Marketing Science 24(4): 338-349.

Baker SM, Gentry JW, Rittenburg TL. 2005. Building Understanding of the Domain of Consumer Vulnerability. Journal of Macromarketing 25(2): 128-139.

Baker SM, Kaufmann-Scarborough C. 2001. Marketing and Public Accommodation: A Retrospective on Title III of the Americans with Disabilities Act. Journal of Public Policy and Marketing 20: 297-304.

Beuningen J, Ruyter K, Wetzels M, Streukens S. 2009. Customer Self-Efficacy in Technology-Based Self-Service. Journal of Service Research 11(4): 407-428.

Biddle BJ. 1986. Recent Developments in Role Theory. Annual Review of Sociology 12: 67-92.

Bitner MJ, Booms BH, Mohr LA. 1994. Critical Service Encounters: The Employee's Viewpoint. Journal of Marketing 58(4): 95-106.

Bitner MJ, Booms BH, Tetreault MS. 1990. The Service Encounter: Diagnosing Favorable and Unfavorable Incidents. Journal of Marketing 54(1): 71-84.

Bitner MJ, Faranda WT, Hubbert AR, Zeithaml VA. 1997. Customer Contributions and Roles in Service Delivery. International Journal of Service Industry Management 8(3): 193-205.

Blodgett JG, Hill DJ, Tax ST. 1997. The Effects of Distributive Justice, Procedural Justice, and Interactional Justice on Post-Complaint Behavior. Journal of Retailing 73(2): 185-210.

Bowen D. 1986. Managing Customers as Human Resources in Service Organizations. Human Resource Management 25(3): 371-383.

Chebat JC, Slusarczyk W. 2005. How Emotions Mediate the Effect of Perceived Justice on Loyalty in Service Recovery Situations: An Empirical Study. Journal of Business Research 58(5): 664-673.

Claycombe C, Lengnick-Hall C, Inks L. 2001. The Customer as a Productive Resource: A Pilot Study and Strategic Implications, Journal of Business Strategies 16(1): 47-68.

Cornwell BT, Gabel TG. 1996. Out of Sight, Out of Mind: An Exploratory Examination of Institutionalization and Consumption. Journal of Public Policy and Marketing 15(2): 278-295.

Dabholkar PA. 1990. How to improve perceived service quality by increasing customer participation. In Dunlap BJ (ed). Developments in Marketing Science. Academy of Marketing Science: Cullowhee, NC; 483-87.

Daunt KL, Harris LC. 2011. Customers Acting Badly: Evidence From the Hospitality Industry. Journal of Business Research 64(10): 1034-1042.

Davidow M. 2003. Organizational Responses to Customer Complaints: What Works and What Doesn't. Journal of Service Research 5(3): 225-250.

Dellande S, Gilly MC, Graham JL. 2004. Gaining Compliance and Losing Weight: The Role of the Service Provider in Health Care Services. Journal of Marketing 68(3): 78-91.

DeWitt T, Nguyen DT, Marshall R. 2008. Exploring Customer Loyalty Following Service Recovery: The Mediating Effects 
of Trust and Emotions. Journal of Service Research 10(3): 269-81.

Dong B, Evans KR, Zou S. 2008. The Effects of Customer Participation in Co-Created Service Recovery. Journal of the Academy of Marketing Science 36(1): 123-137.

Eisingerich AB, Bell SJ. 2006. Relationship Marketing in the Financial Services Industry: The Importance of Customer Education, Participation and Problem Management for Customer Loyalty. Journal of Financial Services Marketing 10(4): 86-97.

Eisingerich AB, Bell SJ. 2008. Perceived Service Quality and Customer Trust: Does Enhancing Customers' Service Knowledge Matter. Journal of Service Research 10(3): 256-268.

Fullerton RA, Punj G. 1993. Choosing to Misbehave: A Structural Model of Aberrant Consumer Behavior. In McAlister L, Rothschild ML (eds). Advances in Consumer Research, (vol. 20). Association for Consumer Research: Provo, UT; 570-574.

Fullerton RA, Punj G. 1997a. Can consumer misbehaviour be controlled? A critical analysis of two major control techniques. In Brucks M, MacInnis DJ (eds). Advances in Consumer Research, (vol. 24). Association for Consumer Research: Provo, UT; 340-344.

Fullerton RA, Punj G. 1997b. What is consumer misbehaviour. In Brucks M, MacInnis DJ (eds). Advances in Consumer Research, (vol. 24). Association for Consumer Research: Provo, UT; 336-339.

Fullerton RA, Punj G. 2004. Repercussions of Promoting an Ideology of Consumption: Consumer Misbehaviour. Journal of Business Research 57(11): 1239-1249.

Funches V, Markley M, Davis M. 2009. Reprisal, retribution and requital: Investigating customer retaliation. Journal of Business Research 62(2): 231-238.

Goodwin C, Ross I. 1992. Salient Dimensions of Perceived Fairness in Resolution of Service Complaints. Journal of Consumer Satisfaction/Dissatisfaction and Complaining Behavior 2: 87-92.

Greenberg J. 1990. Looking Fair Versus Being Fair: Managing Impressions of Organizational Justice. Research in Organizational Behaviour 12: 111-157.

Gregoire Y, Laufer D, Tripp TM. 2010. A Comprehensive Model of Customer Direct and Indirect Revenge: Understanding the Effects of Perceived Greed and Customer Power. Journal of the Academy of Marketing Science 38: 738-758.

Grönroos C. 1988. Service Quality: The Six Criteria of Good Perceived Service. Review of Business 9(3): 10-13.

Gustaffson A. 2009. Customer Satisfaction with Service Recovery. Journal of Business Research 62(11): 1220-1222.

Harris LC, Ogbanna E. 2010. Hiding Customer Complaints: Studying the Motivations and Forms of Employees' complaint concealment behaviours. British Journal of Management, 21(2): 262-279.

Harris LC, Reynolds KL. 2003. The Consequences of Dysfunctional Consumer Behaviour. Journal of Service Research 6(2): 144-161.

Harris LC, Reynolds KL. 2004. Jaycustomer Behaviour: An Exploration of Types and Motives in the Hospitality Industry. Journal of Services Marketing 18(5): 339-357.

Hart CWL, Heskett JL, Sasser WE, Jr. 1990. The Profitable Art of Service Recovery. Harvard Business Review 68(4): 148-56.

Hill RP. 1991. Homeless Women, Special Possessions, and the Meaning of 'Home': An Ethnographic Case Study. Journal of Consumer Research 18 (3): 298-310.

Hill RP, Stephens DL. 1997. Impoverished Consumers and Consumer Behaviour: The Case of AFDC Mothers. Journal of Macromarketing 17(2): 32-48.

Homburg C, Fürst A. 2005. How Organizational Complaint Handling Drives Customer Loyalty: An Analysis of the Mechanistic and the Organic Approach. Journal of Marketing 69(3): 95-114.

Homburg C, Fürst A. 2007. See No Evil, Hear No Evil, Speak No Evil: A Study of Defensive Organizational Behavior Towards Customer Complaints. Journal of the Academy of Marketing Science 35(4): 523-536.
Kaufman-Scarborough C, Baker SM. 2005. Do People with Disabilities Believe ADA Has Served Their Consumer Interests? Journal of Consumer Affairs 39(1): 1-26.

Keeffe DA, Russell-Bennett R, Tombs A. 2007. The Intentional Use of Service Recovery Strategies to Influence Consumer Emotion, Cognition and Behaviour. In Hartel CEJ, Zerbe WJ, Ashkanasy NM (eds). Proceedings International Conference on Emotions and Organizational Life 2006: Research on Emotion in Organizations - Functionality, Intentionality and Morality, (vol. 3). Emerald Publishing: Bingley, UK; 141-175.

Kelley SW, Skinner SJ, Donnelly JH. 1992. Organizational Socialization of Service Customers. Journal of Business Research 25(3): 197-214.

Konovsky MA. 2000. Understanding Procedural Justice and its Impact on Business Organization. Journal of Management 26(3): 489-511.

Lazarus RS. 1991. Emotion and Adaptation. Oxford University Press: New York, N.Y.

Lee RG, Ozanne JL, Hill RP. 1999. Improving Service Encounters Through Resource Sensitivity: The Case of Health Care Delivery in an Appalachian Community. Journal of Public Policy and Marketing 18(2): 230-248.

Litt J, Gaddis BJ, Fletcher CN, Winter M. 2005. Leaving Welfare: Independence or Continued Vulnerability. Journal of Consumer Affairs 34(1): 82-96.

Lovelock C. 2001. Services marketing: People, technology, strategy, (4th edition). Prentice Hall: Englewood Cliffs, NJ.

Lovelock C, Young R. 1979. Look at Customers to Increase Productivity. Harvard Business Review 57: 168-178.

Lusch R, Brown S, Brunswick G. 1992. A General Framework for Explaining Internal vs. External Exchange. Journal of the Academy of Marketing Science 20(2): 119-134.

Maxham JG, III. 2001. Service Recovery's Influence on Consumer Satisfaction, Positive Word-of-mouth, and Purchase Intentions. Journal of Business Research 54: 11-24.

Maxham JG, III, Netemeyer RG. 2002. Modelling customer perceptions of complaint handling over time: The effects of perceived justice on satisfaction and intent. Journal of Retailing 78: 239-252.

McColl-Kennedy JR, Sparks BA, and Nguyen DT. 2011. Customer's angry voice: Targeting employees or the organization? Journal of Business Research 64(7): 707-713.

McColl-Kennedy JR, Sparks BA. 2003. Application of fairness theory to service failure and service recovery. Journal of Service Research 5(3): 251-66.

Meuter ML, Bitner MJ, Ostrom AL, Brown S. 2005. Choosing among alternative delivery modes: an investigation of customer trial of self-service technologies. Journal of Marketing 69(April): 61-83.

Mills PK, Morris JH. 1986. Clients as partial employees of service organizations: Role development in client participation. Academy of Management Review 11(4): 726-735.

Mittal V, Sarkees M, Murshed F. 2008. The right way to manage unprofitable customers. Harvard Business Review 86(April): 94-102.

Mittal V, Sawhney M. 2001. Learning and using electronic information products and services: A field study. Journal of Interactive Marketing 15(1): 2-12.

Payne A, Storbacka K, Frow P. 2008. Managing the co-creation of value. Journal of the Academy of Marketing Science 36: 83-96.

Penaloza L. 1995. Immigrant consumers: Marketing and public policy considerations in the global economy. Journal of Public Policy and Marketing 14(1): 83-94.

Reynolds KL, Harris LC. 2006. Deviant customer behaviour: An exploration of frontline employee tactics. Journal of Marketing Theory and Practice 14(2): 95-111.

Reynolds KL, Harris LC. 2009. Dysfunctional customer behavior severity: An empirical examination. Journal of Retailing 85(3): $321-55$. 
Río-Lanza AB, Vázquez-Casielles R, Díaz-Martín AM. 2009. Satisfaction with service recovery: Perceived justice and emotional responses. Journal of Business Research 62: 775-781.

Rosenblum D, Tomlinson D, Scott L. 2003. Bottom feeding for blockbuster businesses. Harvard Business Review March: 52-59.

Rust RT, Zeithaml VA, Lemon KN. 2000. Driving customer equity: How customer lifetime value is reshaping corporate strategy. The Free Press: New York.

Schoefer K, Ennew C. 2005. The impact of perceived justice on consumer emotional responses to service complaints experiences. Journal of Services Marketing 19(5): 261-70.

Sharma A. 2008. Improving customer service and profitability through customer intervention in service relationships. Journal of Relationship Marketing 7(4): 327-340.

Singh J. 1990. Voice, exit and negative word of mouth behaviours: An investigation across three service categories. Journal of the Academy of Marketing Science 18(1): 1-15.

Smith AK, Bolton RN, Wagner J. 1999. A model of customer satisfaction with service encounters involving failure and recovery. Journal of Marketing Research 36(August): 356-372.

Tax SS, Brown SW, Chandrashekaran M. 1998. Customer evaluations of service complaint experiences: Implications for relationship marketing. Journal of Marketing 62(April): 60-76.
Vargo SL, Lusch RF. 2008. Service dominant logic: Continuing the evolution. Journal of the Academy of Marketing Science 36: 1-10.

Viswanathan M, Rosa JA, Harris JE. 2005. Decision making and coping of functionally illiterate consumers and some implications for marketing management. Journal of Marketing 69(1): $15-31$.

Webster C, Sundaram DS. 1998. Service consumption and criticality in failure recovery. Journal of Business Research 41(2): 153-159.

Weiss HM, Suckow K, Cropanzano R. 1999. Effects of justice conditions on discrete emotions. Journal of Applied Psychology 84(5): 786-94.

Yi Y, Nataraajan R, Gong T. 2011. Customer participation and citizenship behavioral influences on employee performance, satisfaction, commitment, and turnover intention. Journal of Business Research 64: 87-95.

Zeithaml VA, Rust RT, Lemon KN. 2001. The customer pyramid: Creating and serving profitable customers. California Management Review 43(4): 118-142.

Zhao Y, Zhao Y, Song I. 2009. Predicting new customers' risk type in the credit card market. Journal of Marketing Research 46 (August): 506-517. 